\title{
Becoming an entrepreneurial university? A case study of knowledge exchange relationships and faculty attitudes in a medium-sized, research-oriented university
}

\author{
Arianna Martinelli $\cdot$ Martin Meyer $\cdot$ Nick von Tunzelmann
}

Published online: 28 February 2007

(C) Springer Science+Business Media, LLC 2007

\begin{abstract}
This paper seeks to contribute to the growing literature on the entrepreneurial university by mapping knowledge exchange relationships of entrepreneurial faculty in a comprehensive manner and also capturing faculty attitudes towards measures taken by the university administration to promote entrepreneurship. We report on an exploratory study of Sussex University, a medium-sized, researchoriented university, which launched technology transfer activities in the mid-1990s. Our results show that, in spite of a comparatively late start, a considerable number of researchers engage in knowledge exchange processes with industry and other nonacademic partners. We present evidence that suggests faculty in the social sciences and humanities as well as natural sciences and engineering maintain links to industrial partners, including multinational corporations. Furthermore, our observations indicate that schools differ in the way their faculty engage in university-industry collaborations. Further differences can be observed with respect to faculty attitudes towards technology transfer and awareness of the university's respective codes of practice.
\end{abstract}

Keywords University-industry collaboration · Academic entrepreneurship · European university

JEL Classification $\mathrm{O} 3 \cdot 031 \cdot \mathrm{L} 3 \cdot \mathrm{I} 20$

\footnotetext{
A. Martinelli $(\square)$

Department of Technology Management, ECIS Eindhoven Centre for Innovation Studies, University of Technology, Eindhoven, Netherlands

e-mail: a.martinelli@tm.tue.nl

M. Meyer $\cdot \mathrm{N}$. von Tunzelmann

SPRU Science and Technology Policy Research, Freeman Centre, Brighton BN1 9QE, UK

M. Meyer

Institute of Strategy and International Business, Helsinki University of Technology, Espoo, Finland
}

M. Meyer

Steunpunt O\&O Statistieken, K.U. Leuven, Leuven, Belgium 


\section{Introduction}

\subsection{Background: between 'entrepreneurial university' and 'academic entrepreneurship'}

The university is an institution with a long history and, over the course of the centuries, it has gone through several stages in its development. While initially conceived as an institution with a teaching 'mission', the university later adopted a knowledge generation function (research). In recent years, the idea has emerged that the university is assuming a 'third mission', contributing to society and economic development more directly. This process has been conceptualised in different ways: for instance, as a change in the 'social contract' between university and state (Guston \& Keniston, 1994), as a shift between modes of knowledge production (Gibbons et al., 1994) or as the emergence of the Triple Helix Model (Leydesdorff \& Etzkowitz, 1996). Numerous articles based on case studies have suggested that even though universities could share some ultimate goals they have different histories, traditions and organisational structures. These elements can shape universities' attitudes toward relationships with external institutions and therefore they affect their outlook on knowledge exchanges and technology transfers (Bercovitz, Feldman, Feller, \& Burton, 2001; O'Shea, Roche, Allen, \& Chevalier, 2005). This branch of literature shows that there is high heterogeneity, there is no such thing as a typical university, and there is no typical way to be or become an entrepreneurial university.

Arguably, external knowledge relations, even if only informal, can become the seed-bed for more 'contractual' and 'formalized' knowledge exchange and transfer leading up to spin-out firms and licensing arrangements with established firms (e.g. Landry, Amara, \& Oumit, 2002). Following a broad understanding of the notion, one might even call maintaining and extending these links 'entrepreneurial', much in the spirit of Clark's $(1998,2004)$ work on entrepreneurial transformation in European institutions of higher education. Clark used the term as a characteristic of social systems, i.e., entire universities, their internal departments, research centers, faculties and schools:

"An entrepreneurial university, on its own, actively seeks to innovate how it goes about its business. It seeks to work out a substantial shift in organizational character so as to arrive at a more promising posture for the future. Entrepreneurial universities seek to become 'stand-up' universities that are significant actors on their own terms" (Clark, 1998, p. 4).

Based on his research in Europe, Clark $(1998,2004)$ identified five elements that characterized entrepreneurial change:

- a strengthened steering core,

- an expanded developmental periphery, which reaches beyond traditional university boundaries to include outreach offices, such as TTOs, industrial liaison, etc., or also interdisciplinary research centers in more flexible organisational settings,

- a diversified funding base,

- a stimulated academic heartland,

- an integrated entrepreneurial culture. 
Obviously, such a definition is quite different from approaches that primarily view university entrepreneurialism as a university's capacity to spin off new ventures in order to exploit its IP (Shane, 2004). As some have argued (e.g. Meyer, 2003), one may indeed distinguish at least two breeds of innovation agents in the university: the 'entrepreneurial academic' and the 'academic entrepreneur', the latter being the archetypical start-up entrepreneur and the former resembling the 'innovative' faculty member in Clark's sense.

As many observers of science-based innovation processes have pointed out, ${ }^{1}$ the capitalisation of knowledge is a multifaceted, complex, diverse, and interrelated coevolutionary process. One might argue that, to appreciate the entrepreneurship phenomenon in this context, Clark's definition is too broad while Shane's could possibly be too narrow to capture fully the university's entrepreneurial potential (e.g. Tijssen, 2006). Our research seeks to inform research on either side of this definitional divide by focusing on external knowledge exchange relationships of faculty members and faculty attitudes towards university measures that are directed at furthering both more outreach and entrepreneurial activity.

\subsection{Objectives of this study}

Differently from many quantitative studies that appear to zoom in on a few measurable aspects, ${ }^{2}$ our study seeks to put these activities in the context of broader processes encompassing also 'softer' approaches to UITT. Our survey captures Sussex University's network generated by knowledge exchanges at the individual level; to the extent these establish a link with firms this reveals entrepreneurship. Another aspect we aim to explore in this paper is to capture faculty attitudes and awareness with respect to technology transfer activities pursued by the university. While the Triple Helix framework emphasises new opportunities and challenges for the universities arising from a major involvement in economic activities and from the increasing demand for learning, other observers hold a rather pessimistic view, seeing the university and its fundamental academic values and thereby the culture of 'open science' under threat (Dosi, Llerena \& Sylos-Labini 2005; Ziman, 2000). ${ }^{3}$ While there is a debate in the literature on these issues, we still know comparatively little about researcher attitudes towards these issues.

The aim of this paper is to map Sussex University's external relations and to uncover its knowledge exchanges and its UITT network. This would shed some light about its own entrepreneurial orientation and look at the attitudes of its faculty. First we present a brief overview of related literature, focusing in particular on stakeholders involved and channels of knowledge exchange. After a brief description of the context of this study, Sussex University and its technology-transfer history, we outline our methodological approach. The following section presents the key findings of our survey and maps out the variety of knowledge exchange links that university faculty have established. Differences between 'schools' of study within the

${ }^{1}$ For instance, see Carayannis and Campbell (2006), Etzkowitz and Leydesdorff (1997, 2000), Gibbons et al. (1994), Kline and Rosenberg (1986), Leydesdorff (2003), Leydesdorff and Meyer (2003, 2006), Rothwell (1992), or Nightingale (1998).

${ }^{2}$ See e.g. the critical review in Langford, Hall, Josty, Matos, and Jacobson (2006).

${ }^{3}$ Other scholars who dispute the novel character of the 'shift' toward the applied end rather see the emergence of the 'third mission' as a phenomenon that has been present since the Middle Ages; therefore it does not represent a 'menace' for universities (Geuna, 1998; Martin, 2003). 
University are explored, as well as researcher attitudes. The final section will present some conclusions.

\section{University-industry relations}

\subsection{Actors involved}

Collaboration between university and industry faces challenges because both university and industry resemble heterogeneous pools of actors, each with its characteristics, purposes and structures. The new economics of science has sometimes referred to them as the 'Republic of Science' and the 'Realm of Technology', pointing to how deep the differences can be between them (Dasgupta \& David, 1994). Siegel, Waldam and Link (2003) identify three different stakeholders that are directly involved in university-industry relations but are characterised by distinct strategies and scope: university scientists, technological transfer offices (TTOs) and firms/entrepreneurs. Siegel et al. (2003: 42) find "that UITT stakeholders operate under different organizational environments and cultures, implying that they have different norms, standards and values." The main differences in motives and organisational structure are reported in Table 1. The authors argue this can lead to conflicts in which, for instance, TTO managers are accused of being too aggressive in bargaining, or act in an excessively bureaucratic fashion.

Numerous studies have specifically focussed on these actors in order to highlight their crucial characteristics for successful technology transfer and to explain some performance differential across universities. UK TTOs are less efficient than those in the USA and it is suggested they should foster improvements by looking at the US experiences (Chapple et al., 2005). Different aspects of TTOs can affect the UITT outcome, first of all its organisational structure that shape its incentive structures and capabilities (Bercovitz et al., 2001) and the quality of its officers (Lockett \& Wright, 2005).

Other researchers concentrate on individual characteristics as factors affecting technology transfer processes. Changes in faculty attitudes have increased the rate of innovation disclosures to TTOs and therefore determined an increase in patenting

Table 1 Stakeholders in university-industry relations

\begin{tabular}{|c|c|c|c|}
\hline Stakeholder & University Scientist & TTO & Firm/entrepreneur \\
\hline Actions & $\begin{array}{l}\text { Discovery of new } \\
\text { knowledge }\end{array}$ & $\begin{array}{l}\text { Work with faculty and } \\
\text { firm/entrepreneur } \\
\text { to structure deal }\end{array}$ & $\begin{array}{l}\text { Commercialise new } \\
\text { technologies }\end{array}$ \\
\hline Primary motive & $\begin{array}{l}\text { Recognition within the } \\
\text { scientific community }\end{array}$ & $\begin{array}{l}\text { Protect and market } \\
\text { the university's } \\
\text { intellectual property }\end{array}$ & Financial gain \\
\hline $\begin{array}{l}\text { Secondary } \\
\text { motive }\end{array}$ & $\begin{array}{l}\text { Financial gain and } \\
\text { desire to secure } \\
\text { additional research } \\
\text { funding }\end{array}$ & $\begin{array}{l}\text { Facilitate technological } \\
\text { diffusion and secure } \\
\text { additional research } \\
\text { funding }\end{array}$ & $\begin{array}{l}\text { Maintain control } \\
\text { over proprietary } \\
\text { technologies }\end{array}$ \\
\hline $\begin{array}{l}\text { Organisational } \\
\text { culture }\end{array}$ & Scientific & Bureaucratic & Entrepreneurial \\
\hline
\end{tabular}

Source: Siegel et al. (2003) 
by universities (Thursby \& Thursby, 2002). Louis, Blumenthal, Gluck, and Stoto (2001) argue that individual characteristics and perceptions about potential risks of external links for scientific values may explain the personal propensity to different types of entrepreneurship better than university policies and organisation. Success or failure in fostering technological transfers often depends on the willingness of faculty to participate actively in this process. In order to ensure faculty collaboration it is important to set up the right bundle of incentives and mitigate moral hazard problems with regard to inventor effort (Jensen \& Thursby, 1998).

University spin-offs (USOs) represent a resource intensive way to transfer knowledge and more actors can be involved, especially for providing financial support. The parent organisation, the technology originator, the entrepreneur and the venture investor interact in different ways and they determine different ways to spin out new ventures (Roberts \& Malone, 1996).

\subsection{Channels of exchange}

Concerning the production, use and exchange of knowledge the Triple Helix framework stresses the importance of the emergence of trilateral and hybrid networks among University, Industry and Government (Leydesdorff \& Meyer, 2003). In the same way, the role of universities in the development of innovative clusters (and therefore of local networks) has been discussed in numerous cases, most notably in studies about Silicon Valley, Route 128 and Cambridge (e.g. Feldman, 1994; Kogut, 2000; Senker, 2007).

Scholars have recognised the importance of networks as organisational structures and network analysis has focussed on the process of relations that connect individuals or organisations and on the subsequent emerging structures. Studies have shed some light on network formation (Larsons \& Starr, 1993) and relational aspects, showing that networks can be conceptualised as informal ties among individuals (Granovetter, 1995; Murray, 2002) or on the contrary as formal contracts or strategic alliances (Kogut, 2000; Powell, Koput \& Smith-Doerr, 1996).

Recently, literature on networks has concentrated on geographic characteristics and the organisational structure of the nodes. The diffusion of information through formal links depends not only on the density of the network but also on the goals of the institutions involved (Owen-Smith \& Powell, 2004), and structural differences (heterogeneity of actors and number of cross-national relations) in US and European biotech networks underline differences in basic science production and its level of integration (Owen-Smith, Riccaboni, Pammolli \& Powell, 2002).

As emerged in the previous section, University and Industry present substantial differences and they interact in many different ways, which implies different levels of commitment and risk by the parts. The literature has mainly dealt with formal interactions like patenting and licensing, USOs, research grants, collaborative research, research students and consultancies, although informal ones also deserve some attention.

Landry et al. (2002) conceptualise technological transfer as consisting of several stages ranging from transmission (contacting firms and informing them of potentially relevant research) to commercialisation in the narrow sense. Their econometric analysis indicates that researchers tend to be much more involved in first-stage activities than in activities closer or immediately related to commercialisation. This research emphasies the importance of less formal mechanisms of knowledge 
exchange. Furthermore, Murray points out that ties between the science and technology networks are often rather informal and according to their research take place through conferences, consulting, boarding and research students (Murray, 2002).

The general view on university patent activity is rather optimistic and tends to focus more on the positive aspects, mainly the increase in availability of funds. On the negative side, using patents could lead to a substitution effect between publishing and patenting (Geuna \& Nesta, 2006). Also there is evidence of a (relatively weak) "anti-commons effect", where the appropriation of a piece of knowledge through intellectual property tends to decrease the likelihood of its future citations and therefore of its indepth exploration (Murray \& Stern, 2005). There is particular concern about the shift from basic research to more applied, with potential long-run problems. ${ }^{4}$ Other possible drawbacks related to the research university's function include:

- undermining exchange and collaboration among departments,

- the rising stringency of university IPR policies to accomplish the proprietary knowledge view of industry (Nelson, 2001),

- a delay of publications of new scientific findings or a reticence in their disclosure (Blumenthal, Campbell, Causino, \& Luis, 1997),

- damage to teaching functions resulting from the encouragement to spend more time in commercial activities and also a weakening of the trust climate (Feldman \& Desrochers, 2003; Louis et al., 1989; Stephan, 2001).

Scientists from physical sciences and life sciences have different perceptions about the protection that a patent can offer. Both see the patent as a means to gain freedom, but from different points of view. For physical scientists a patent implies feeling free to present their results; instead, for life scientists the freedom derives from the fact that if someone else (usually a private firm) takes out the patents before academic research on the same topic it can be blocked. Costs of patenting generally depend on the perception of the quantity of time and resources that should be spent on interacting with TTOs (Owen-Smith \& Powell, 2001).

Universities can have different policies about patent management, but in a large number of countries, universities retain the property of the patent and share the income with the inventors (OECD, 2003). TTOs can have different organisational forms that imply different strategies and priorities, yet one of the most important seems to be the search of alternative sources of funding (Mowery, Nelson, Sampat, \& Zeidonis 2001; Siegel et al., 2003). As Thursby, Jensen, and Thursby (2001) show in their analysis of licensing contracts, patents are typically licensed at an early stage. While large firms seem to prefer to license inventions at a later stage, small firms prefer licensing early-stage inventions. In this sense, small firms may have an advantage in appropriating research-based inventions (Thursby et al., 2001).

The creation of new ventures from a university's TTO represents a complex and risky process that requires a broad range of capabilities such as providing finance,

\footnotetext{
${ }^{4}$ However, it should be noted that there is little empirical evidence in favour of this notion. Quite the contrary, case studies seem to point in the other direction. For instance, Ranga, Debackere, and von Tunzelmann (2003) did not find any evidence of this phenomenon in their case study of the Catholic University of Leuven. Also with respect to the patenting-publication trade-off, the evidence base is not clear. In the area of nano-structured science and technology, for instance, patenting scientists seem to outperform their non-inventing peers in terms of publication and citation frequency (Meyer, 2006).
} 
business links, managerial and marketing advice (Lockett, Wright, \& Vohora, 2004). New venture creation is particularly an option if the new technology has a high degree of tacitness, is difficult to transact by a patent, or a contract licence were to underestimate the value of the invention (Franklin, Wright \& Lockett, 2001). Some variables seem to affect the likelihood for successful USOs, these are: previous successes, the quality of the faculty, industry funding coupled with national research funding for life sciences and chemistry and commercial resources (O'Shea et al., 2005)

\subsection{Context of the study: Sussex University}

Sussex University is located in Brighton in South-East England, a well-off and industrialised region that accounts for the $15.6 \%$ of the total UK Gross Value Added in 2003. Like many other British universities, Sussex University is a post-war Higher Education Institution (HEI). It received its Royal Charter in 1961, along with six other 'new universities' (Warwick, York, Lancaster, Essex, East Anglia, and Kent), together they became known as the 'Seven Sisters' and were seen as "a unique phenomenon: the only universities since London and Durham to leap into existence fully armed, with the whole panoply of first and postgraduate degrees, curricula designed from scratch, in brand new buildings on virgin sites, able to create themselves in whatever image they chose" (Perkin, 1991: 295).

The 'Seven Sisters' were unlike siblings at the time, with Sussex and Warwick being at different ends of the continuum. In Sussex, the idea was not just to "assemble a collection of distinguished academics and leave them to get on with it as individuals" but to stress 'active teams' (Briggs, 1991, 320 \& 321; cf. Clark, 1998, 12). Here, 'interdisciplinarity'-also then very much discussed and en vogue-was translated into an organisational framework that did not acknowledge 'departments' (or 'faculties') in the traditional sense but only broad 'schools'. Even today the University is still organised in 'Schools' and 'Graduate Research Centres'; departments, however, have been introduced as the Schools' organisational subunits.

Warwick followed a different approach, according to observers at the time: "There was a different way of conceiving of a new university, best represented, I believe, at Warwick. Bring professors in and leave them free to get on with it" (Briggs, 1991, 324). Even though the development was not all that clear-cut as it might seem today, Warwick did give entrepreneurial researchers the space and operational freedom early on and benefited subsequently from returns that resulted from such activities. Also, relatively soon after its foundation, a business school was set up. The university administration sought to instil a pro-business attitude and make it a 'relevant university' in the regional economic context while also emphasising 'academic excellence' (Clark, 1998, ch.2).

At Sussex the focus was clearly on scholarship and research in the traditional sense, albeit in a strongly cross-disciplinary context. While taking a different path of development, Sussex University might also be viewed as a success story. In 40 years the University has become a centre of excellence in both teaching and research, documented in the results of teaching quality and research assessment exercises, the level of the research grants received and the reputation of its faculty. Even though comparatively small, with less than 1,000 faculty members, it has managed to gain a position among the leading universities in research-based rankings of UK HEIs (see 
e.g. overview in Shattock, 2003). Two Sussex faculty members have received Nobel prizes. ${ }^{5}$

Currently, the University is going through a phase of restructuring, in some respects, even pushing further the idea of broad, cross-disciplinary Schools. In 2004, in which our study was carried out, the 11 old schools were replaced by just 5: the School of Humanities, Life Sciences (LifeSci), Social Sciences and Cultural Studies (SocCul), Science and Technology (SciTech), and the Sussex Institute. Each School includes departments and research centres. The university includes also Science and Technology Policy Research (SPRU) and the very recent Brighton and Sussex Medical School (BSMS).

In the last few years, the British government has tried to foster universities' involvement in IP management and technology transfer (HM Treasury \& DTI, 1998). In order to respond to this policy Sussex University has made substantial efforts to enhance its entrepreneurial capacity. Most notably, it has extended its 'developmental periphery' to foster the development of different types of external relationships in order to transfer technology, including the establishment of a Regional Development Office and a dedicated IP office ('Sussex IP'). Apart from this, one needs to mention the Sussex Innovation Centre ('SInC'), which can be viewed as one of the more successful incubators in the region.

\section{Methodology}

\subsection{Overall approach}

As the previous section illustrated, a rich literature about university-industry relationships exists and a wide range of research tools has been applied, both qualitative and quantitative. As knowledge exchanges may occur in different forms we chose a survey approach to explore these phenomena in more detail.

This study explores entrepreneurial outreach and faculty links at an individual level. Not all knowledge exchange and related entrepreneurial activities are tracked or even controlled by the university administration. Only an analysis at the individual level can provide a comprehensive picture encompassing both formal entrepreneurial exchange (for instance: spin-offs, licences, consultancies, and research contracts) and informal types of knowledge exchange. Moreover, a survey allows collecting personal data about the level of 'entrepreneurial culture', namely the faculty's beliefs and their perceptions concerning university involvement with industry.

\subsection{Data collection}

The questionnaire we circulated for our survey provides information about the individual activities and allows us to collect not only the names of the partner organisations but also the types of collaborations among them. Therefore, we could exploit information not only about the node of the network but also about the relations. These maps, differently from similar exercises like the Cambridge

\footnotetext{
5 They are now affiliated with other universities.

篮 Springer
} 
Phenomenon and the Techmap, ${ }^{\circledR}$ do not concentrate on the time dimensions, as Sussex University's involvement with the external world is a recent occurrence, but deal more with the relations between the scientific domain of the external links and the industrial sector. In this case a classification of counterpart organisations is required. Classifications are often arbitrary, incomplete and nonexhaustive, especially if they are based on product sector. In order to avoid part of these problems we decided to use a simple scheme based on the aggregation of the Financial Times Classification, whereby the six sectors derived are: Biomed, Technology, Media, ITSIS, Traditional and Telecommunication ${ }^{6}$ (Bottazzi \& Da Rin, 2002). Two categories are added in order to complete the spectrum of University partners: Other and Government Organisations. ${ }^{7}$

\subsection{Mapping the university's network}

A descriptive point of view has been selected for this research and one of the main outcomes of the article is a map of Sussex University's knowledge exchanges; different types of links emerge and it is possible to distinguish the most common forms of technology transfer like licensing. As the literature points out that some relevant aspects and perceptions of knowledge exchanges are shaped according to the research field (for which Schools here represent a proxy), the collected data are analysed at two different levels: the individual and the School. The mapping is a tool in order to visualise the network and analyse its characteristics. The mapping of a network centred on a university or PROs is not new; well-known examples are the Cambridge Phenomenon that traced the network of firms related to Cambridge University departments since the 1950s (SQW, 1985), the Techmapreg in Canada and the Bioclusters (Owen-Smith \& Powell, 2004).

A network map can be constructed using information provided by different sources, and the basic aim is to establish a relationship criterion between the nodes; the knowledge exchange literature has extensively dealt with network analysis conducted using the connection provided by university-industry co-patenting or co-publications. Setting the correct level of network analysis is fundamental for the relevance of the results and their interpretation (Miettinen, 1994). The maps constructed for this paper are not entirely constructed at individual level; in fact the nodes are external organisations (e.g. the Schools, private firms, research councils, charities, etc.), but individuals (the academic faculty) have established the connections.

\footnotetext{
${ }^{6}$ The six sectors are constructed using the following aggregation: Biomed (includes chemicals, diversified, health, pharmaceuticals, personal care), Technology (includes construction, engineering, electrical products, electronics, household goods), Media (includes leisure and media), Telecommunication, Traditional (includes food, forestry, steel, distribution, transport), ITSIS (IT services, internet and software includes software, automotive services, retailers).

${ }^{7}$ The first comprises all the Research Councils and governmental agencies and the second involves energy firms, financial and services firms.
} 
Table 2 Distribution of external relations across Schools

\begin{tabular}{|c|c|c|c|c|c|}
\hline \multirow[t]{3}{*}{ School } & \multirow[t]{3}{*}{ Total } & \multicolumn{4}{|c|}{ Involvement } \\
\hline & & \multicolumn{2}{|l|}{ Yes } & \multicolumn{2}{|l|}{ No } \\
\hline & & Number & $\%$ & Number & $\%$ \\
\hline Humanities & 123 & 2 & 1.60 & 17 & 13.80 \\
\hline LifeSci & 260 & 23 & 8.90 & 25 & 9.60 \\
\hline SciTech & 185 & 7 & 3.80 & 21 & 11.40 \\
\hline SocCul & 142 & 8 & 5.60 & 19 & 13.40 \\
\hline Anonymous & & 26 & & 25 & \\
\hline Total & & 66 & & 107 & \\
\hline
\end{tabular}

Note: The percentages are calculated considering the total number of faculty of each School

\section{Empirical results}

\subsection{Response rate and entrepreneurial involvement}

The survey was conducted through a web-based questionnaire and a personal e-mail was sent to 710 Sussex University faculty members ${ }^{8}$. The number of academics who completed the questionnaire was 173 . The response rate is $24 \%$, this figure can be considered a reasonable response rate within the UK context. Not all the respondents have contacts with external partners, on the contrary, only $38 \%$ do. Table 2 depicts the distribution of faculty with external relations across Schools in order to bring to light the polarisation between Schools and research fields.

LifeSci is the school with the largest involvement with the non-academic world, followed surprisingly by SocCul. The school of Humanities has the lowest level of external connections, assuming our responses are a true random sample. The anonymous constitute a consistent group in both parts and it is a pity to be unable to affiliate them to a school.

\subsection{External relations}

\subsubsection{Types of knowledge exchange}

Sussex University academics have been asked about specific forms of knowledge exchanges they have had in the last 5 years and about their counterparts. The list in the questionnaire includes seven different types (based on Landry et al., 2002) and is ordered according to an increasing level of involvement:

- Transmission: I have sent my research results to private firms, government agencies and other users outside the academic milieu;

- Presentation: I have been invited to present my research results to groups and organisations who could make direct use of them;

- Effort: I have been asked to sit in on working groups that were involved in direct efforts to apply new knowledge including my own research;

\footnotetext{
8 The survey was sent to Professors, Lecturers, Readers, Research Fellows and Research Officers. It doesn't include Ph.D. students because their external collaborations can be traced through their supervisors.

型 Springer
} 
- Consultation: I have provided consulting services to private firms, government agencies or organizations associated with my research field;

- Use: The use of my research results has contributed to the development of new or improved goods or services;

- Business activities: I am involved in business activities outside laboratories that are related to my research activities;

- Commercialisation: Others have attempted to commercialise the results of my research.

At Sussex University, the most commonly chosen category is Consultation, in line with findings by Landry and colleagues in their Canadian study, while the 'softer' categories of 'Presentation' and 'Transmission' also represent important means of interactions, especially for the LifeSci School. These categories do not involve any economic and commercial transactions, and despite being considered just like core activities for academics, yet they may represent first steps (often also initial contacts) leading to a process of sustained knowledge transfer. Business Activities and Commercialisation (that according to Shane's definition are indicators of entrepreneurial activities) are present but are the least selected options. This is not surprising as they entail long and more resource-intensive processes. Our results also illustrate that Schools are not homogeneous about the size and the type of their external relationships. Humanities have few external links whereas LifeSci shows an irregular profile: high percentages in four categories and almost zero in the others. SciTech and SocCul illustrate similar levels but the former has a more even profile than the latter (see Fig. 1 for an overview).

\subsubsection{External links of Sussex Schools...}

This section presents more specific data as to how Sussex faculty liaise with external partners using the seven categories devised in the Higher Education-Business Interaction Survey (2000/01). ${ }^{9,10}$ Table 3 summarises the links of Sussex University's knowledge exchange network.

It further confirms our previous finding that Sussex University relations with the external world take place chiefly by way of consultancy. Collaborative research and research grants are also important forms of knowledge exchange. As theory suggests there are some individual differences across Schools it is interesting to look at their distribution across Schools; LifeSci and SciTech together account for more than half the links in each category and they cover almost the whole spectrum of possibilities, in fact they include departments like Biochemistry, Chemistry, Mathematics and Physics and Astronomy, all disciplines that strongly rely on basic research.

We can now look at the specific way through which Sussex Schools and external partners interact and we can observe some differences (Table 4): LifeSci is mainly involved in collaborative research and SciTech in consultancy. Moreover, some scarcely surprising information emerges: the highest shares of collaborative research, research grants and research students are carried out by the LifeSci School, and this

\footnotetext{
9 For detailed definitions see Appendix.

${ }^{10}$ In the questionnaire there was also a question about spin-offs but Sussex University does not show a developed tradition about them although there is at least a very successful example. The biotechnology company Genpack was funded in 1993 and after merging with Genetix Group PLC in 2000 it was quoted on the stock market in early 2001 with a value of $£ 100$ million.
} 


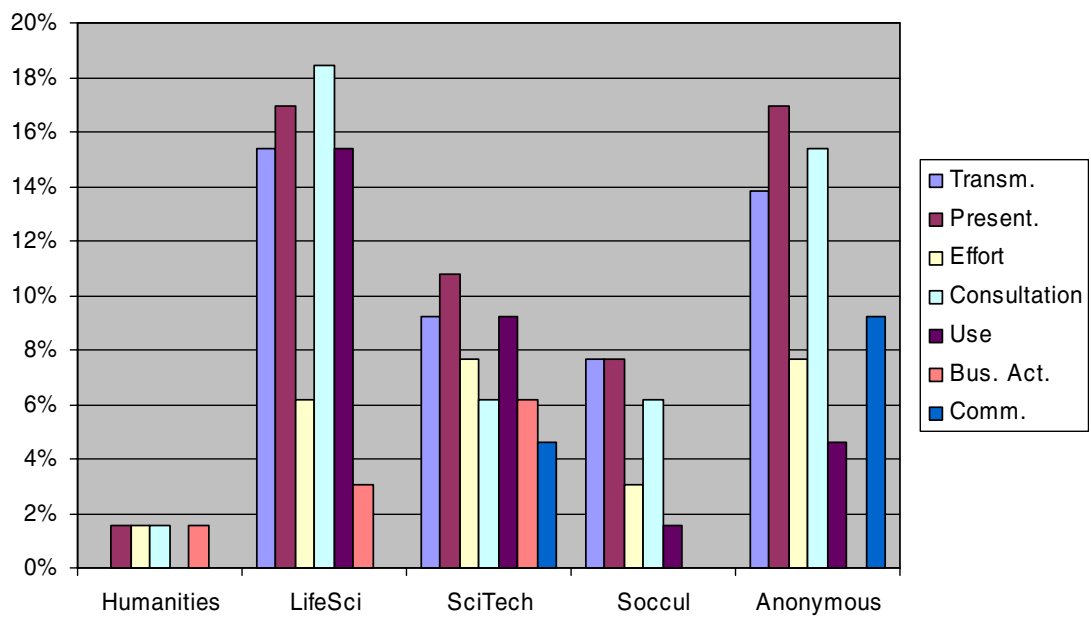

Fig. 1 Predominance of technology transfer types across Schools

Table 3 External links by type

\begin{tabular}{llllllll}
\hline Patents & Consultancy & $\begin{array}{l}\text { Collaborative } \\
\text { research }\end{array}$ & $\begin{array}{l}\text { Research } \\
\text { contract }\end{array}$ & $\begin{array}{l}\text { Research } \\
\text { grant }\end{array}$ & $\begin{array}{l}\text { Research } \\
\text { students }\end{array}$ & KTS & Total \\
\hline Total $3(1.9 \%)$ & $44(28.2 \%)$ & $41(26.3 \%)$ & $11(7.1 \%)$ & $38(24.4 \%)$ & $18(11.5 \%)$ & $1(0.6 \%)$ & 156 \\
\hline
\end{tabular}

Note: Percentages are calculated on the total

Key: See Appendix

Table 4 Distribution of links for Schools and types

\begin{tabular}{|c|c|c|c|c|c|c|c|c|}
\hline School & Patents & Consultancy & $\begin{array}{l}\text { Collaborative } \\
\text { research }\end{array}$ & $\begin{array}{l}\text { Research } \\
\text { contract }\end{array}$ & $\begin{array}{l}\text { Research } \\
\text { grant }\end{array}$ & $\begin{array}{l}\text { Research } \\
\text { students }\end{array}$ & KTS & Total \\
\hline \multirow[t]{3}{*}{ Humanities } & & 3 & 2 & & 3 & & & 8 \\
\hline & & $7 \%$ & $5 \%$ & & $8 \%$ & & & \\
\hline & & $38 \%$ & $25 \%$ & & $38 \%$ & & & \\
\hline \multirow[t]{3}{*}{ LifeSci } & 1 & 16 & 23 & 4 & 19 & 11 & & 74 \\
\hline & $33 \%$ & $36 \%$ & $56 \%$ & $36 \%$ & $50 \%$ & $61 \%$ & & \\
\hline & $1 \%$ & $22 \%$ & $31 \%$ & $5 \%$ & $26 \%$ & $15 \%$ & & \\
\hline \multirow[t]{3}{*}{ SciTech } & 1 & 10 & 9 & 3 & 5 & 2 & & 31 \\
\hline & $33 \%$ & $23 \%$ & $22 \%$ & $27 \%$ & $13 \%$ & $11 \%$ & $100 \%$ & \\
\hline & $3 \%$ & $32 \%$ & $29 \%$ & $10 \%$ & $16 \%$ & $6 \%$ & $3 \%$ & \\
\hline \multirow[t]{3}{*}{ SocCul } & & 6 & 2 & 2 & 4 & 1 & & 15 \\
\hline & & $14 \%$ & $5 \%$ & $18 \%$ & $11 \%$ & $6 \%$ & & \\
\hline & & $40 \%$ & $13 \%$ & $13 \%$ & $27 \%$ & $7 \%$ & & \\
\hline \multirow[t]{3}{*}{ Anonymous } & 1 & 9 & 5 & 2 & 7 & 4 & & 28 \\
\hline & $33 \%$ & $20 \%$ & $12 \%$ & $18 \%$ & $18 \%$ & $22 \%$ & & \\
\hline & $4 \%$ & $32 \%$ & $18 \%$ & $7 \%$ & $25 \%$ & $14 \%$ & & \\
\hline Total & 3 & 44 & 41 & 11 & 38 & 18 & 1 & \\
\hline
\end{tabular}

Note: The first percentage refers to the columns (types of link) and the second to the rows (Schools) Key: See Appendix 
School accounts also for $36 \%$ of consultancy, still the largest though in this case the gap with other Schools is less evident. Patents and research grants were also considered and their distributions have a more even pattern.

\subsection{3 ... and its entrepreneurial activities}

In order to look at knowledge exchange interactions that underline entrepreneurial activities external partners need to be classified. Moreover, the classification will shed some light on the relation between scientific research field (represented by the Schools) and industrial sectors. The 92 partners identified by the questionnaire were classified into 8 different sectors; Table 5 shows that the majority belong to Industry and that only $33 \%$ are Governmental Organisations. It is important to point out this figure because, despite our holistic definition, we cannot consider links with these institutions as entrepreneurial activities.

Maps reported in Fig. 2 visualise the entire network centred on each School and also their entrepreneurial activities; they depict differences among Schools and types of link. In particular, some research fields predominantly interact with particular sectors and others spread their expertise and knowledge across many sectors. Looking at types of links, Table 6 shows the sectoral distribution of external links.

All the sectors show a particular interest in university expertise through consultancy, except the Technology sector which prefers to interact through collaborative research. Biotechnology based sectors strongly rely on the basic research provided by the University, therefore their large involvement in knowledge exchanges is rather predictable. The Biomed sector seems to prefer collaborative research, consultancies and research students. Moreover, two out of the three patent licences are with biomedical firms, which is not surprising as patents are known to be an effective way of appropriation in the biopharmaceutical sector. Government organisations relate to the University in two ways: research grants from Research Councils and consultancies provided to a large number of governmental departments and agencies.

The other two Schools have a small number of external relations and are concentrated on Government Agencies or Other (mainly charities), but there are some exceptions: in fact Humanities is connected with Microsoft (Software) and SocCul with Fiat (Traditional).

\subsubsection{Regional knowledge spillovers}

Knowing University partners' names allows a search for their location; it emerges that only $9 \%$ of partner firms are located in East Sussex, rising to $16 \%$ if we consider the South-East as a whole. This percentage is smaller than for firms located in the rest of England and for those abroad. In particular Sussex University has many

Table 5 Number of partners and their sectors

\begin{tabular}{lllllllll}
\hline Sector & Biomed & Traditional & ITSIS & Technology & Media & Telecom & Other & Gov. Org. \\
\hline Number & 19 & 4 & 4 & 4 & 6 & 4 & 21 & 30 \\
$\%$ & 21 & 4 & 4 & 4 & 7 & 4 & 23 & 33 \\
\hline
\end{tabular}

Note: Percentages are calculated on the total (92) 
A. Martinelli et al.
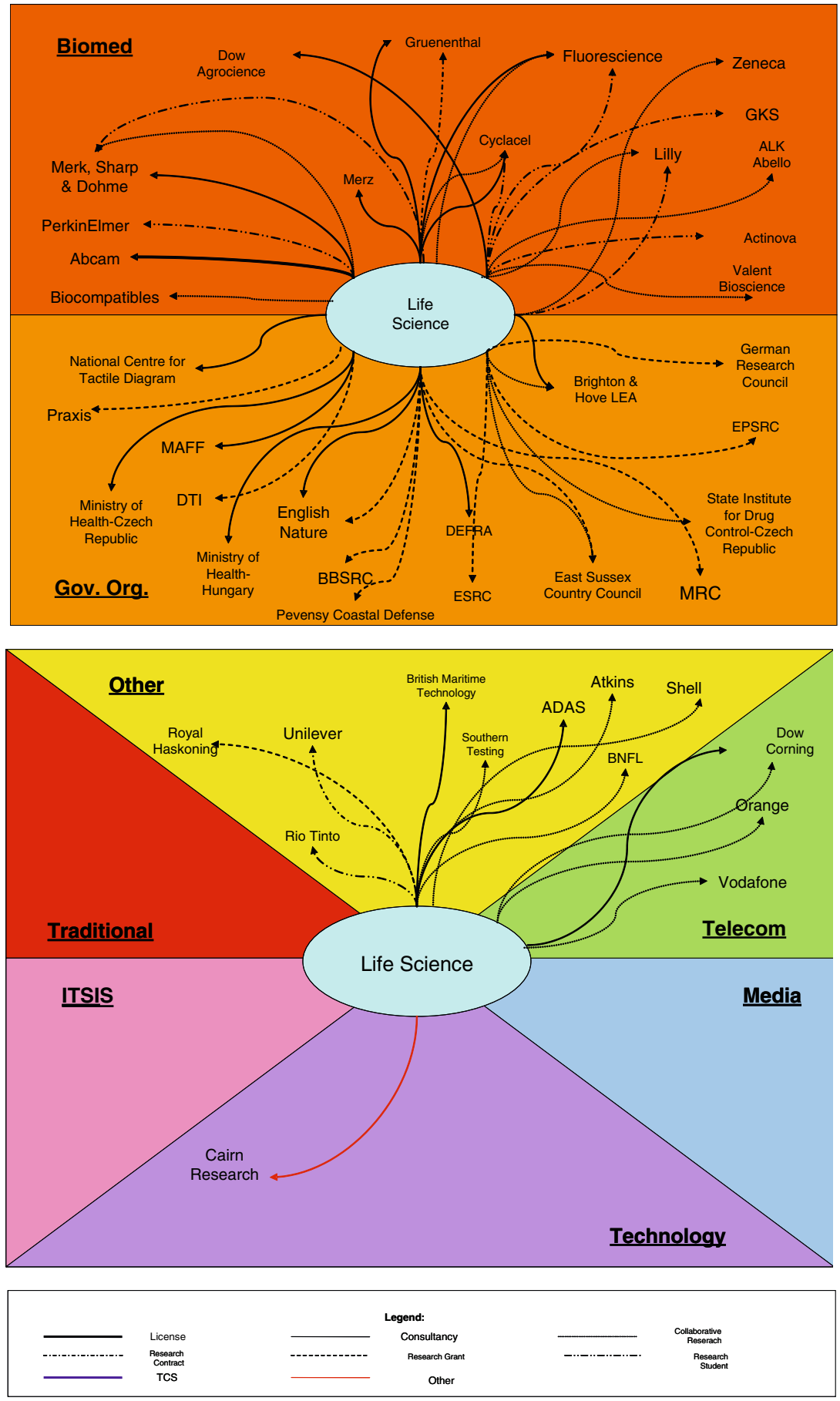

Fig. 2 External relations of selected Schools 

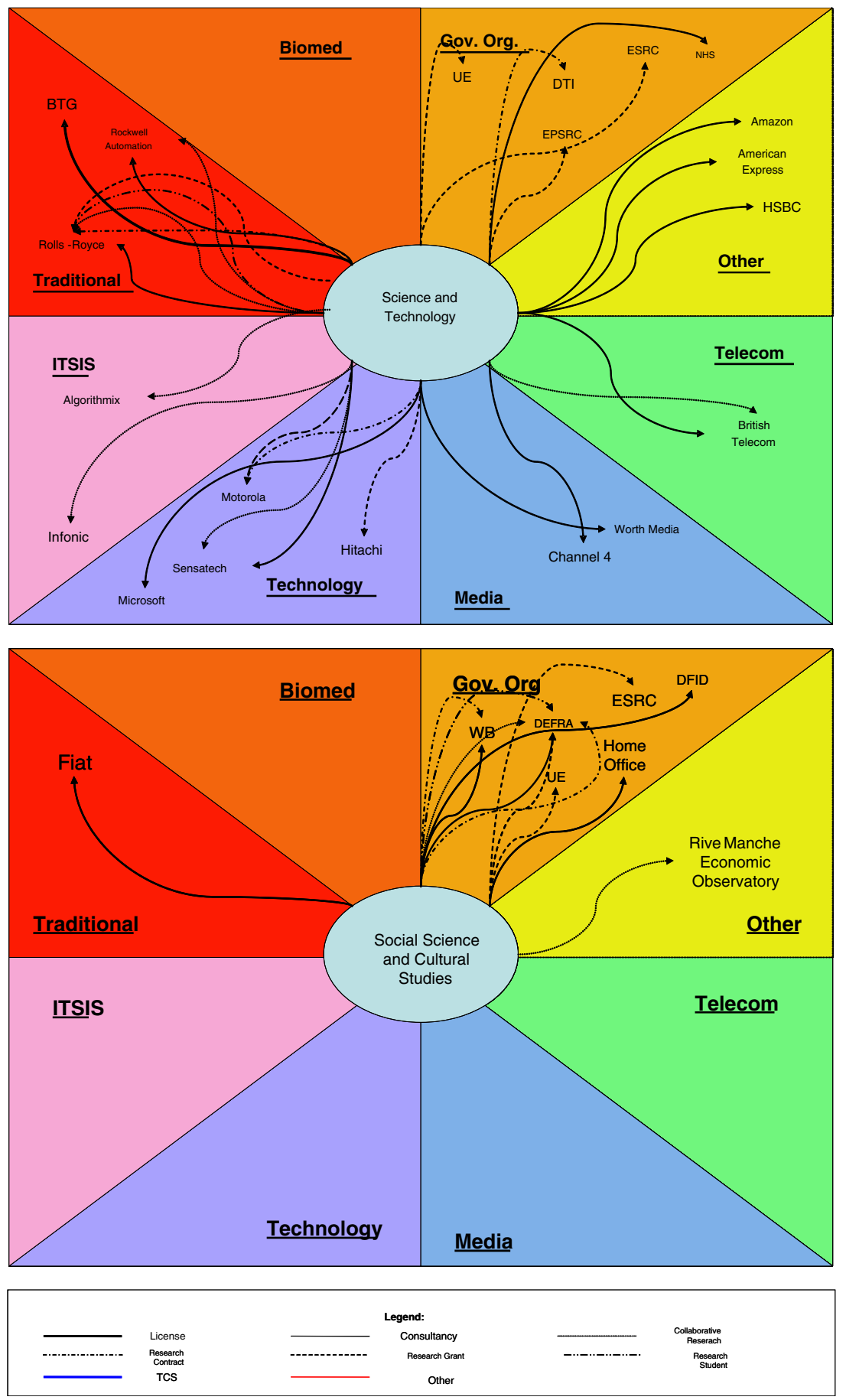

Fig. 2 continued 
A. Martinelli et al.
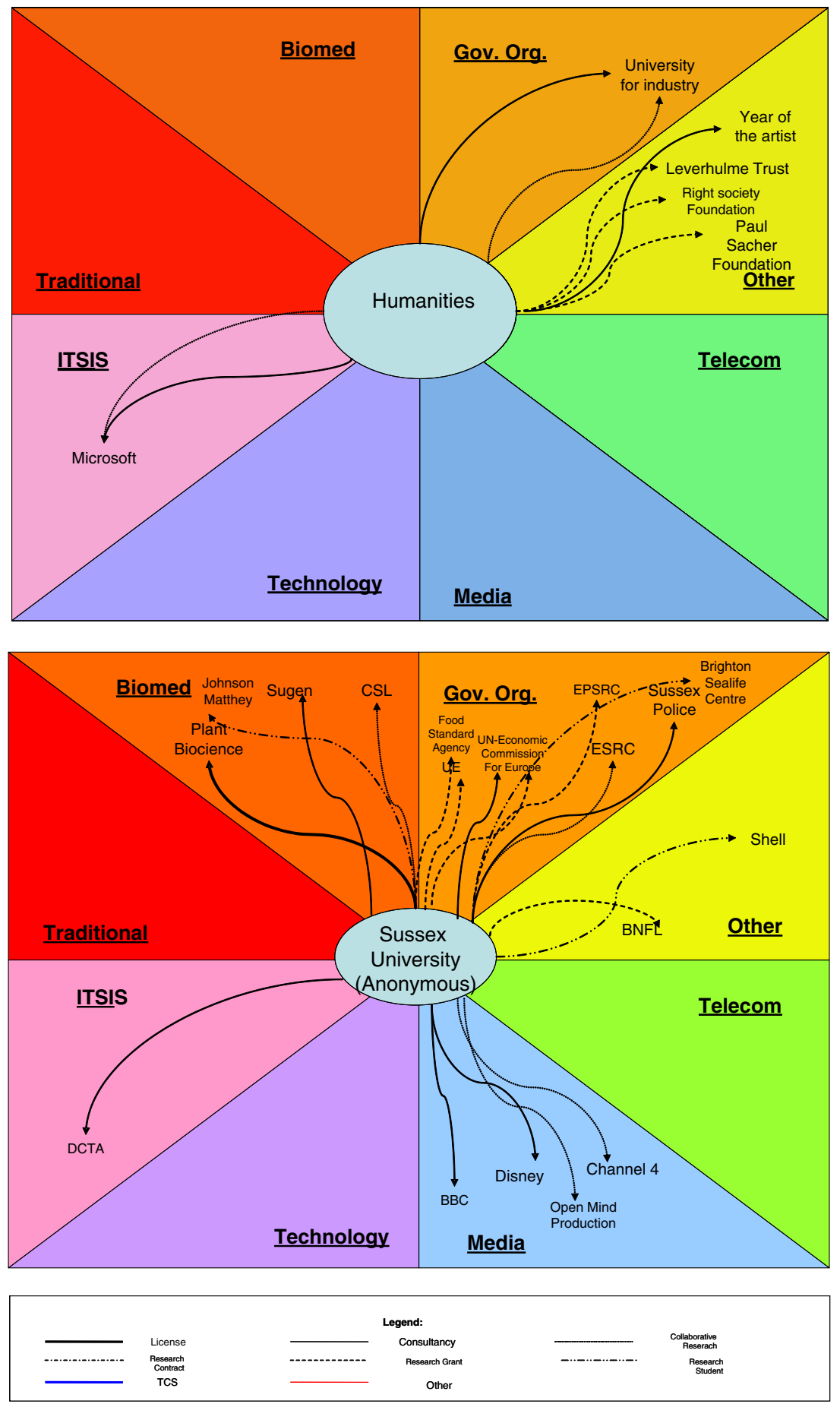

Fig. 2 continued 
Table 6 Sectoral distribution of external links

\begin{tabular}{|c|c|c|c|c|c|c|c|}
\hline Sector & Patent & Consultancy & $\begin{array}{l}\text { Collaborative } \\
\text { research }\end{array}$ & $\begin{array}{l}\text { Research } \\
\text { contract }\end{array}$ & $\begin{array}{l}\text { Research } \\
\text { grant }\end{array}$ & $\begin{array}{l}\text { Research } \\
\text { students }\end{array}$ & KTS \\
\hline \multirow[t]{2}{*}{ Biomed } & 2 & 7 & 9 & 1 & 3 & 9 & \\
\hline & $6 \%$ & $23 \%$ & $29 \%$ & $3 \%$ & $10 \%$ & $29 \%$ & \\
\hline \multirow[t]{2}{*}{ Traditional } & 1 & 4 & 3 & 1 & 1 & 2 & \\
\hline & $8 \%$ & $33 \%$ & $25 \%$ & $8 \%$ & $8 \%$ & $17 \%$ & \\
\hline ITSIS & & $\begin{array}{l}3 \\
60 \%\end{array}$ & $\begin{array}{l}3 \\
60 \%\end{array}$ & & & & \\
\hline \multirow[t]{2}{*}{ Technology } & & 1 & 2 & 1 & & & 1 \\
\hline & & $20 \%$ & $40 \%$ & $20 \%$ & & & $0.20 \%$ \\
\hline \multirow[t]{2}{*}{ Media } & & 4 & 3 & & & & \\
\hline & & $57 \%$ & $43 \%$ & & & & \\
\hline \multirow[t]{2}{*}{ Telecom } & & 1 & 4 & & & & \\
\hline & & $20 \%$ & $80 \%$ & & & & \\
\hline \multirow[t]{2}{*}{ Other } & & 6 & 8 & 3 & 9 & 3 & \\
\hline & & $21 \%$ & $28 \%$ & $10 \%$ & $31 \%$ & $10 \%$ & \\
\hline \multirow[t]{2}{*}{ Gov. Org. } & & 18 & 9 & 5 & 25 & 4 & \\
\hline & & $29 \%$ & $15 \%$ & $8 \%$ & $40 \%$ & $6 \%$ & \\
\hline Total & 3 & 44 & 41 & 11 & 38 & 18 & 1 \\
\hline
\end{tabular}

Note: Percentages refer to columns, and therefore to sectors

foreign partners and this is recognition of its high reputation. On the other hand, knowledge exchange processes may not have the kind of impact on the regional economy that stakeholders in the South-East may wish. In the light of this development the establishment of a Regional Development Office of the University seems timely.

\subsection{Attitudes \& faculty awareness}

\subsubsection{Personal outlook}

Following Clark's definition of the entrepreneurial university, it is also important to look at the level of entrepreneurial culture in the faculty. Part of the questionnaire was devoted to this and explores individual opinions concerning external linkages. Faculty members were asked to express their (dis)agreement about certain remarks that express different dimensions of possible tensions emerging from such external activities. These are: (1) the possible increase of pressure on faculty members to spend too much time on commercial activities; (2) the possible shift towards applied research; (3) the possible delay in disclosure of new findings; (4) the possible undermining of cooperative activities within departments; (5) the possible generation of debates among academics who support and those who oppose business links; (6) the possible change in standards for promotion and tenure; (7) the possible reduction of faculty involvement in teaching.

Responses are analysed in two different ways: firstly according to their external involvement and secondly according to their Schools. The comparison of individual opinions between people who have external links and people who have not should point out if there are 'prejudices' about the links with the non-academic world.

As Table 7 illustrates, there are no considerable differences between the two groups. However, it is interesting to note that, except for one category (Applied Research), the group without external links exhibits somewhat lower values, which 
Table 7 Individual opinions about external involvement

Obs. Pressure Applied Delay Cooperation Debate Standards Teaching research

\begin{tabular}{lllllllll}
\hline With external & \multirow{2}{*}{63} & 2.8 & 2.1 & 2.7 & 3.4 & 2.9 & 2.9 & 3.0 \\
involvement & & 0.975 & 0.939 & 0.985 & 0.873 & 0.847 & 0.932 & 1.008 \\
No external involvement & 48 & 2.6 & 2.1 & 2.6 & 3.0 & 2.7 & 2.6 & 2.7 \\
& & 0.739 & 0.751 & 0.871 & 0.752 & 0.869 & 0.58 & 0.829 \\
Total & \multirow{2}{*}{111} & 2.7 & 2.1 & 2.7 & 3.2 & 2.9 & 2.7 & 2.9 \\
& & 0.882 & 0.858 & 0.934 & 0.84 & 0.859 & 0.809 & 0.942
\end{tabular}

Note: The scale is from 1 (strong agreement) to 5 (disagreement). The second number in the cells is the standard deviation

Table 8 Individual opinions according to School

\begin{tabular}{|c|c|c|c|c|c|c|c|c|}
\hline & Obs. & Pressure & Applied research & Delay & Cooperation & Debate & Standards & Teaching \\
\hline \multirow[t]{2}{*}{ Humanities } & 4 & 2.5 & 2.0 & 2.0 & 2.3 & 2.3 & 1.8 & 2.0 \\
\hline & & 0.577 & 0.816 & 0.816 & 0.957 & 0.957 & 0.957 & 0.816 \\
\hline \multirow[t]{2}{*}{ LifeSci } & 34 & 2.6 & 1.9 & 2.7 & 3.1 & 3.0 & 2.9 & 2.9 \\
\hline & & 0.925 & 0.769 & 0.994 & 0.946 & 0.797 & 0.702 & 1.026 \\
\hline \multirow[t]{2}{*}{ SciTech } & 16 & 2.9 & 2.3 & 2.6 & 3.3 & 2.8 & 2.8 & 3.1 \\
\hline & & 0.915 & 0.704 & 0.915 & 0.594 & 1.033 & 0.799 & 1.000 \\
\hline \multirow[t]{2}{*}{ SocCul } & 13 & 2.2 & 1.7 & 1.9 & 2.4 & 2.4 & 2.3 & 2.4 \\
\hline & & 0.825 & 0.439 & 0.961 & 0.953 & 0.877 & 0.877 & 1.016 \\
\hline \multirow[t]{2}{*}{ Anonymous } & 44 & 2.9 & 2.3 & 2.8 & 3.4 & 2.9 & 2.8 & 3.0 \\
\hline & & 0.852 & 1.020 & 0.892 & 0.726 & 0.813 & 0.815 & 0.792 \\
\hline
\end{tabular}

Note: The second number in the cells is the standard deviation

highlights a generally more negative view about the external linkages in comparison with the group that has them. However the differences are mostly not very large. ${ }^{11}$

The analysis across Schools (Table 8) seems to corroborate earlier observations that the Schools that are more involved with industry (LifeSci and SciTech) tend to have a more positive outlook on involvement with industry. Our data indicate that LifeSci faculty, unlike their SciTech colleagues, believe that external involvement brings about a shift towards applied research. ${ }^{12}$ This point is quite controversial in the literature because, even though this point is always cited among the drawbacks of an increase of links between industry and university, there is no strong empirical evidence as yet in support.

While our data all in all seem to support the notion that external links do not undermine cooperation within the faculty we did come across anecdotal evidence to the contrary. For instance, a respondent noted: "I have encountered previous cooperating scientists in the same corridor of the same department having to avoid discussing their findings with each other due to conflicting commercial backing. This is

\footnotetext{
${ }^{11}$ The $t$-test for the equality of the two sub-samples' means is significant only for cooperation, standards and teaching. These data depict the existing situation but do not necessarily prove a causal relationship between the negative perception of external links and the lack of them.

${ }^{12}$ This observation sheds some light also on the contradictory result for the 'Applied Research' category observed in Table 7. As LifeSci faculty represent the most numerous group in the 'External involvement' sub-sample, it seems that the Applied Research result is mainly driven by their particular negative opinion.
} 
counterproductive." This statement may represent an isolated case but it highlights a specific fact and not only an impression.

\subsubsection{The university's codes of practice and faculty awareness}

Sussex University has a Code of Practice on Intellectual Property, Commercial Exploitation and Financial Benefits, and a Consultancy Code. In our survey we explored faculty awareness of and attitudes towards these codes. Clearly, the Codes of Practice represent a sensitive topic as they regulate the financial aspects of both activities and in the case of consultancy also the time that teaching faculty are allowed to spend on it. ${ }^{13}$ A confirmation of this comes from the low rate of completion of responses. This part was completed by 123 persons, but only $46(37.4 \%)$ declared that they know the IP Code and only 31 (25.2\%) assessed it. The Consultancy Code seems to be even less well-known, with only $38(30.1 \%)$ affirming to know it and $28(22.7 \%)$ to evaluate it. The evaluation was based on a rating scale from 1 (low) to 5 (high) in four dimensions:

- Strictness that measures how much faculty perceive the codes as a limitation for their activities;

- Economic fairness evaluates the sharing of revenues and extra income derived from IPRs and consultancy;

- Suitability for you is the extent to which the codes are adequate for faculty needs;

- Suitability for your partners is the extent to which the codes are adequate for external partners.

Even though the observed values are rather high for both codes of practices we cannot trace any statistically significant difference between them. However, a $t$-test suggests that some variables are significantly different: the IP Code is considered stricter and less economically fair. The literature suggests that perceptions about IPR and their policies may be shaped according to the research field; therefore it is worth looking at the average evaluation within Schools. As the data presented in Table 9 show, LifeSci and SciTech faculty have different views on the two documents. LifeSci academics find the IP code stricter, less economically fair and less suitable for the partners than SciTech academics. Moreover, the IP code appears not to suit the needs of LifeSci faculty very much. Generally, they evaluate the Consultancy Code better. ${ }^{14}$ Unfortunately, ANOVA tests of equality of multiple means are only very weakly significant.

A closer look at the academics involved in activities that are directly affected by the Codes yields interesting observations. This applies in particular to the Consultancy Code. While 37 respondents declared an involvement in consultancy activities, just $52 \%$ indicated they were aware of the Code. The low response rate and choice not to assess the code (even if people confess to know them) seem to point to some

\footnotetext{
13 The Code of Practice on Intellectual Property, Commercial Exploitation and Financial Benefits obliges all staff (and staff responsible for supervising student academic work) to report any intellectual property that may have commercial value. The commercial exploitation is led by Sussex IP, which owns all the IPR generated at Sussex University and undertakes all the application and protection costs. Inventors and Schools will share parts of the royalties eventually received.

${ }^{14}$ SciTech faculty has the opposite view; they are better suited by the IP code rather than the Consultancy Code.
} 
Table 9 Faculty perceptions of IP and consultancy codes

\begin{tabular}{|c|c|c|c|c|c|c|c|c|}
\hline & \multicolumn{4}{|l|}{ IP code } & \multicolumn{4}{|c|}{ Consultancy code } \\
\hline & Strictness & $\begin{array}{l}\text { Economic } \\
\text { Fairness }\end{array}$ & $\begin{array}{l}\text { Suitability } \\
\text { for } \\
\text { you }\end{array}$ & $\begin{array}{l}\text { Suitability } \\
\text { for } \\
\text { partners }\end{array}$ & Strictness & $\begin{array}{l}\text { Economic } \\
\text { Fairness }\end{array}$ & $\begin{array}{l}\text { Suitability } \\
\text { for you }\end{array}$ & $\begin{array}{l}\text { Suitability } \\
\text { for } \\
\text { partners }\end{array}$ \\
\hline \multirow[t]{2}{*}{ Anonymous } & 3.6 & 2.8 & 2.9 & 2.9 & 3.6 & 3.0 & 3.0 & 2.6 \\
\hline & 0.966 & 0.919 & 0.994 & 0.928 & 1.272 & 1.464 & 1.291 & 1.512 \\
\hline \multirow[t]{2}{*}{ Humanities } & 3.5 & 2.5 & 2.0 & 1.0 & 3.5 & 3.0 & 2.0 & 1.0 \\
\hline & 0.707 & 0.707 & 0 & - & 0.707 & 0 & 0 & - \\
\hline \multirow[t]{2}{*}{ LifeSci } & 3.6 & 3.0 & 2.6 & 2.6 & 3.3 & 2.8 & 3.1 & 3.4 \\
\hline & 0.768 & 0.954 & 0.985 & 0.667 & 0.675 & 0.919 & 1.101 & 0.726 \\
\hline \multirow[t]{2}{*}{ SciTech } & 3.2 & 2.8 & 3.0 & 2.2 & 3.7 & 3.2 & 3.0 & 2.6 \\
\hline & 0.837 & 0.837 & 0.707 & 0.837 & 0.516 & 0.753 & 0.894 & 0.894 \\
\hline \multirow[t]{2}{*}{ SocCul } & 3 & 3 & 3 & 3 & 3 & 3 & 3 & 3 \\
\hline & - & - & - & - & - & - & - & - \\
\hline Total & 3.38 & 2.83 & 2.70 & 2.34 & 3.41 & 2.99 & 2.82 & 2.52 \\
\hline
\end{tabular}

Note: The second number in the cells is the standard deviation

level of dissatisfaction with Consultancy and also the IP regulations. ${ }^{15}$ At the very least the observations seem to point to a need for more awareness-creating measures.

\section{Conclusions}

\subsection{Connections beyond patenting, licensing and spin-outs}

This paper illustrates the multifaceted links of university faculty with non-academic actors. Maps show that Sussex University is at the centre of a dense network of relations with non-academic partners and the interactions may take place in different ways often not captured by the most common quantitative indicators. According to our holistic definition, the presence and the development of this network are indicators of entrepreneurialism. The data show differences in orientations between Schools and while the extent of entrepreneurial links to non-academic actors may vary, an interesting finding is that entrepreneurial academics can be found in both 'hard' science/engineering and humanities/social science departments. Not surprisingly, the Life Science and science and Engineering schools exhibited the highest share of externally linked, entrepreneurial academics. Yet we could also identify considerable activity in Arts and Humanities and Social Science.

\subsection{Differences between Schools and Science Fields}

The analysis at the individual level reveals the presence of different types of contacts, and of the importance of informal knowledge exchanges that do not involve

\footnotetext{
15 Of the five respondents who declared to be involved in patenting (three received royalties, one has just applied and the last is involved in a spin-off with IP ownerships), only four answered that they knew the IP Code and three evaluated it (generally not in a positive way: highly strict and low suitability). One should expect that all of them knew it and were able to form an opinion about it. Sussex University adopts a broad definition of IP and therefore it does not cover only patents, but this is the only IP category clearly recognisable by the questionnaire.
} 
commercial and economic transactions. In general, Sussex faculty appear to be more drawn to consultancy, collaborative research agreements and contract research than patenting and licensing or starting up a company. However, data confirm differences across research fields. For instance, the LifeSci School links up to external partners mainly through collaborative research agreements, while SciTech School faculty prefer consultancy arrangements.

\subsection{Expected and unexpected links}

Maps depict a strong involvement with Biomed firms and government organisations, and visualise different patterns emerging from LifeSci and SciTech Schools. Although we cannot consider government organisations as entrepreneurial partners they are part of Sussex University's network and these links anyway represent a resource (in term of money, reputation and people) for the university. LifeSci's external links are highly polarised between the Biomed sector and the governmental organisations; instead, SciTech's involvement is more spread across different sectors. Moreover, a number of unexpected connections such as links between Humanities faculty and Microsoft, the School of Social Science \& Cultural Studies and Fiat. We also traced links between the Life Science school and telecom companies. ${ }^{16}$

\subsection{Varying levels of awareness and different perceptions of technology transfer}

Other findings complete the picture about Sussex University and can help to explain its peculiar pathway toward entrepreneurship. Theory points out the importance of individual beliefs and behaviours in order to succeed in technology transfer, and at Sussex University, academics without any external relations perceive the involvement with industry as risky for values of the scientific community; they seem to believe to a somewhat greater extent that establishing a business relation causes a decrease in cooperation within the department, a change in standards and tenures, and a reduction of faculty interest in teaching.

Some interesting results come out from the analysis relating to the assessment of the University's Code of Practice for IPR and Consultancy. Faculty show a low level of awareness of these documents; furthermore, the general evaluation is quite negative, as they are considered strict, economically unfair and not really suitable. Furthermore, the emergence of consultancy as a primary form of interaction with industry has some implications for the University's policies and in particular for IP. In setting research contracts or collaborative research, bargaining for the IP ownership of eventual future outcomes is often a deterrent to University and Industry collaborations. In the case of consultancy, no IP issues emerge as the (economic) value of the knowledge is not embedded in physical products but in the relation itself.

\subsection{Limitations: how representative is the case?}

This study presents two main limitations: the cross-sectional approach and the special context. The former refers to our longitudinal approach that does not allow

${ }^{16}$ It was not possible to explore in detail the activity of the academic with external links with Telecom firms; we can only say that it is a Research Fellow of the Psychology Departments whose academic interests are usability, user experiences and interfaces. 
appreciation of changes over time and development; furthermore, the paucity of data about specific aspects of the relations mapped (i.e. frequencies, economic arrangements and specific contents) does not allow deriving causal relations but just taking a static picture of a situation and drawing some descriptive statistics.

Finally, it is impossible to leave aside the special context and background of the case examined without discussing how much to generalise from the results obtained in this investigation. Sussex University may be representative of a specific category of British university: it is an example of the so-called 'new universities' created in the 1960s. A distinctive point of Sussex University has been its focus on an interdisciplinary approach for teaching and research. This principle led the organisational changes in 2004 that designed the new Schools structure, where their number was further reduced in favour of a major concentration. The maps that relate the Schools to the industrial sectors in some way capture this effort toward interdisciplinary and diversity as they clearly visualise the fact that each School is related to several different sectors. This attention to cross-border research and diversity has often meant a tension between academic achievements and University structure. Finally, a distinctive feature of Sussex University that could represent a limit on the generalisation of the results is its location in one of the most economically developed regions. This aspect is mitigated by finding that the majority of Sussex University partners are not located in the South-East of England, so Sussex University through its efforts in research excellence and reputation is able to broaden the geographical horizon of its external relations.

\section{Appendix: Typology of external linkages}

- Royalty from patents.

- Consultancy: expert advisory or analysis services.

- Collaborative research: project in which academics and Industry work together on shared problems.

- Research Contract: projects that are in response to a specification by the funding body.

- Research grant: fund received by government or charitable funding bodies, following a proposal drawn up by academic researcher(s).

- Research student: businesses sponsor individual student.

- Knowledge Transfer Scheme (TCS formerly): company takes on a graduate to develop a new product or process with the full back-up of Sussex University.

- Other (to be specified).

\section{References}

Bercovitz, J., Feldman, M., Feller, I., \& Burton, R. (2001). Organizational structure as determinants of academic patent and licensing behavior: An exploratory study of Duke, Johns Hopkins, and Pennsylvania State Universities. Journal of Technology Transfer, 26, 21-35.

Blumenthal, D., Campbell, E. G., Causino, M. S., \& Luis, K.S. (1997). Withholding research results in academic life science: Evidence from a national survey of faculty. Journal of the American Medical Association, 227, 1224-1228.

Bottazzi, L., \& Da Rin, M. (2002). Europe's 'new' stock markets, IGIER Working Papers no. 218.

Briggs, L. A. (1991). A founding father reflects. Higher Education Quarterly, 45, 311-332. Cited after Clark (1998:12).

Springer 
Carayannis, E. G., \& Campbell, D. F. J. (Eds.) (2006). Knowledge creation, diffusion and use in innovation networks \& clusters: A comparative systems approach across the US, Europe and Asia. Greenwood: Praeger.

Chapple, W., Lockett, A., Siegel, D., \& Wright, M. (2005). Assessing the relative performance of university technology transfer offices in the UK: Parametric and non-parametric evidence. Research Policy, 34(3), 369-384.

Clark, B. R. (1998). Creating entrepreneurial universities organizational pathways of transformation. New York: IAU Press.

Clark, B. R. (2004). Sustaining change in universities: Continuities in case studies and concepts. Maidenhead: Society for Research into Higher Education \& Open University Press.

Dasgupta, P., \& David, P. A. (1994). Toward a new economics of science. Research Policy, 23, 487521.

Dosi, G., Llerena, P., \& Sylos-Labini, M. (2005). Science-Technology-Industry Links and the "European Paradox": Some Notes on the Dynamics of Scientific and Technological Research in Europe, LEM Working Papers number 2005/02.

Etzkowitz, H., \& Leydesdorff, L., (Eds.) (1997). Universities in the global knowledge economy: A Triple Helix of university-industry-government relations. London: Pinter.

Etzkowitz, H., \& Leydesdorff, L. (2000). The dynamics of innovation: From national systems and 'Mode 2' to a Triple Helix of university-industry-government relations' Research Policy 29, 109_ 123.

Feldman, M. P. (1994). An examination of the geography of innovation. Industrial and Corporate Change, 2, 312-333.

Feldman, M., \& Desrochers, P. (2003). Research universities and local economic development: Lessons from the history of the Johns Hopkins University. Industry and Innovation, 10(1), 5-24.

Franklin, S., Wright, M., \& Lockett, A. (2001). Academic and surrogate entrepreneurs in university spin-out companies. Journal of Technology Transfer, 26, 127-141.

Geuna, A. (1998). The internationalisation of the European university: A return to medieval roots. Minerva 36, 253-270.

Geuna, A., \& Nesta, L. (2006). University patenting and its effects on academic research: the emerging European evidence. Research Policy, 35(6), 790-807.

Gibbons, M., Limoges, C., Nowotny, H., Schwartzman, S., Scott, P., \& Trow, M. (1994). The new production of knowledge: The dynamics of science and research in contemporary societies. London: Sage Publications.

Granovetter, M. (1995). Economic action and social structure: The problem of embeddedness. American Journal of Sociology, 91, 481-510.

Guston, H., \& Keniston, K. (1994). Introduction: the social contract for science. In H. Guston \& K. Keniston (Eds.), The fragile contract, Cambridge, Mass: The MIT Press.

Higher education-business interaction survey (2000-01).

HM Treasury DTI. (1998). Innovating for the future: investing in R\&D. London: Stationery Office.

Jensen, R., \& Thursby, M. (1998). Proof and prototypes for sale: The tale of university licensing, NBER Working Papers no. 6698.

Kline, S., \& Rosenberg, N. (1986). An overview of innovation. In R. Landau \& N. Rosenberg (Eds.), The positive sum strategy: Harnessing technology for economic growth. Washington, DC: National Academy Press.

Kogut, B. (2000). The network as knowledge: Generative rules and the emergence of structure. Strategic Management Journal, 21, 405-25.

Landry, R., Amara, N., \& Oumit, M. (2002). Research transfer in natural science and engineering: Evidence from Canadian universities, paper presented at 4th Triple Helix Conference, Copenhagen, Denmark.

Langford, C., Hall, J., Josty, P., Matos, S., \& Jacobson, A. (2006). Indicators and outcomes of Canadian University Research: Proxies becoming goals. Research Policy, 35(10), 1586-1598.

Larson, A., \& Starr, J. A. (1993). A network model of organization formation. Entrepreneurship: Theory and Practice, 17, 5-15.

Leydesdorff, L. (2003). The mutual information of university-industry-government relations: An indicator of the Triple Helix dynamics. Scientometrics, 58(2), 445-467.

Leydesdorff, L., \& Etzkowitz, H. (1996). Emergence of a Triple Helix of university-industry-government relations. Science and Public Policy, 23(5), 279-286.

Leydesdorff, L., \& Meyer, M. (2003). The Triple Helix of university-industry-government relations: A model for innovation in the 'knowledge based' economy. Scientometrics, 58(2), 445-467. 
Leydesdorff, L., \& Meyer, M. (2006). The Triple Helix, indicators, and knowledge-based innovation systems. Research Policy, 35(10), 1441-1449.

Lockett, A., \& Wright, M. (2005). Resources, capabilities, risk capital and the creation of university spin-out companies. Research Policy, 34(7), 1043-1057.

Lockett, A., Wright, M., \& Vohora, A. (2004). Resources, capabilities, risk capital and the creation of university spin-out companies. Mimeo.

Louis, K. S., Blumenthal, D., Gluck M., \& Stoto, M. (1989). Entrepreneurs in academe: An exploration of behaviors among life scientists. Administrative Science Quartely, 34(1), 110-131.

Martin, B. (2003). The changing social contract for science and the evolution of the university. In A. Geuna, A. Salter, \& W. E. Steinmueller (Eds.), Science and innovation: Rethinking the rationale for funding and governance. Cheltenham: Edward Elgar.

Meyer, M. (2003). Academic entrepreneurs or entrepreneurial academics? Research-based ventures and public support mechanisms. $R \& D$ Management, 33(2), 107-115.

Meyer, M. (2006). Are co-active inventors on top of their class? An exploratory comparison of inventor-authors with their non-inventing peers in nano-science and technology. Research Policy, 35(10), 1646-1662.

Miettinen, R. (1994). Methodological issues of studying innovation-related networks. Group of Technology Studies Working papers no.4.

Mowery, C., Nelson, R. R., Sampat B. N., \& Ziedonis, A. A. (2001). The growth of patenting and licensing by US universities: An assessment of the effects of the Bayh-Dole act of 1980. Research Policy, 30, 99-199.

Murray, F. (2002). Innovation as co-evolution of scientific and technological networks: Exploring tissue engineering. Research Policy, 31(8-9), 1389-1403.

Murray, F., \& Stern, S. (2005). Do formal intellectual property rights hinder the free flow of scientific knowledge? An empirical test of the anti-commons hypothesis, NBER Working Paper number 11465.

Nelson, R. R. (2001). Observations on the post-Bayh-Dole rise of patenting at American universities. Journal of Technology Transfer, 26, 13-19.

Nightingale, P. (1998). A cognitive model of innovation. Research Policy, 27, 689-700.

OECD. (2003). Turning science into business: Patenting and licensing at public research organisations. Paris: OECD.

O'Shea, R., Roche, F., Allen, T., \& Chevalier, A. (2005). Entrepreneurial orientation, technology transfer and spinoff performance of US Universities. Research Policy, 34(7), 994-1009.

Owen-Smith, J., \& Powell, W. (2001). To patent or not: Faculty decision and institutional success at technology transfer. Journal of Technology Transfer, 26, 99-114.

Owen-Smith, J., \& Powell, W. W. (2004). Knowledge networks as channels and conduits: The effects of spillovers in the Boston biotechnology community. Organization Science, 15(1), 5-21.

Owen-Smith, J., Riccaboni, M., Pammolli, F., \& Powell, W. W. (2002). A comparison of US and European university-industry relations in the life sciences. Management Science, 48, $24-43$.

Perkin, H. (1991). Dream, myth and reality: New universities in England, 1960-1990. Higher Education Quarterly, 45, 294-310. Cited after Clark (1998:12).

Powell, W., Koput, K., \& Smith-Doerr, L. (1996). Interorganizational Collaboration and the locus of innovation: Networks of learning in biotechnology. Administrative Science Quarterly, 44(1), 111145.

Ranga, L. M., Debackere, K., \& von Tunzelmann, N. (2003). Entrepreneurial universities and the dynamics of academic knowledge production: A case study of basic vs. applied research in Belgium. Scientometrics, 58(2), 265-279.

Roberts, E. B., \& Malone, D. E. (1996). Policies and structures for spinning off new companies from research and development organizations. $R \& D$ Management, 26(1), 17-48.

Rothwell, R., (1992). Successful industrial innovation: Critical success factors for the 1990 s. $R \& D$ Management, 22(3), 221-239.

Segal, Quince, \& Wicksteed. (1985). The Cambridge phenomenon. Cambridge: Segal, Quince, Wicksteed Limited.

Senker, J. (2007), An analysis of policies to promote bio-clusters in Europe. Environment and Planning $C$ (forthcoming).

Shane, S. (2004). Academic entrepreneurship: University Spinoffs and Wealth Creation. Aldershot, UK: Edward Elgar.

Shattock, M. (2003). Managing successful universities. Maidenhead: Society for Research into Higher Education, Open University Press. 
Siegel, D., Waldam, D., \& Link A. (2003). Assessing the impact of organisational practises on the relative productivity of university transfer offices: An exploratory case. Research Policy, 32(1), $27-48$.

Stephan, P. E. (2001). Educational implications of university-industry technology transfer. Journal of Technology Transfer, 26, 199-205.

Thursby, J., Jensen, R., \& Thursby, M. (2001). Objectives, characteristics and outcomes of university licensing: A survey of major US universities. Journal of Technology Transfer, 26, 59-72.

Thursby, J. G., \& Thursby, M. C. (2002). Who is selling the ivory tower? Sources of growth in university licensing. Management Science, 48, 90-104.

Tijssen, R. J. W. (2006). Universities and industrially relevant science: Towards measurement models and indicators of entrepreneurial orientation. Research Policy, 35(10), 1569-1585.

Ziman, J. (2000). Real science: What it is, and what it means. Cambridge: Cambridge University Press. 